\title{
The effect of the apparent ileal digestible lysine-to-energy ratio on growth rate and protein deposition in the body of growing pigs fed a wheat-rapeseed diet
}

\author{
S. Raj ${ }^{1}$, G. Skiba, D. Weremko and H. Fandrejewski
}

\author{
The Kielanowski Institute of Animal Physiology and Nutrition, \\ Polish Academy of Sciences \\ 05-110 Jabłonna, Poland
}

(Received 16 April 2003; revised version 23 September 2003; accepted 28 October 2003)

\begin{abstract}
The experiment was conducted on 20 pigs from 25 to $70 \mathrm{~kg}$ body weight (BW) to determine the optimal apparent ileal digestible lysine:metabolizable energy (Lys:ME) ratio in a wheat-rapeseed diet. Gilts (synthetic line 990) were allocated to 4 groups. Group 1 was fed a basal diet containing wheat and rapeseed meal (with $4.4 \mathrm{mM} \mathrm{kg}^{-1}$ glucosinolates), without supplementation with any crystalline amino acids and was lysine deficient. Group 2 consumed a basal diet supplemented with $0.21 \%$ L-lysine $\cdot \mathrm{HCl}$, but was still deficient in comparison with the content of other essential amino acids. Group 3 was fed a diet supplemented with $0.42 \% \mathrm{~L}$-lysine $\cdot \mathrm{HCl}, 0.018 \% \mathrm{~L}$-threonine, and $0.015 \%$ L-tryptophan. Group 4 received a diet supplemented with $0.65 \% \mathrm{~L}-\mathrm{lysine} \cdot \mathrm{HCl}$ and $0.053 \%$ DL-methionine to maintain their mutual proportion of 100:32, however the concentration of these amino acids was in excess of the requirement. Supplementation of crystalline lysine to the basal diet was designed to contain a differential Lys:ME ratio: 0.34 (diet 1), 0.47 (diet 2), 0.59 (diet 3), and $0.71 \mathrm{~g} \mathrm{MJ}^{-1}$ (diet 4). The apparent digestibility of amino acids in wheat and rapeseed meal was determined in a separate experiment with surgically modified pigs. All diets were isoproteino (193 $\left.\mathrm{g} \mathrm{kg}^{-1} \mathrm{DM}\right)$ and isoenergetic (14.5 $\left.\mathrm{MJ} \mathrm{kg}^{-1} \mathrm{DM}\right)$. The methionine, threonine and tryptophan contents were close to the recommendations of CVB (1995) or were given in excess.

The gain of chemical body components was determined using the comparative slaughter method. The animal body weight gain and protein deposition in the body were taken as the response criteria. Daily weight gain increased $(\mathrm{P}<0.05)$ from 673 to $808 \mathrm{~g}$ along with the Lys:ME ratio increasing from 0.34 to $0.59 \mathrm{~g} \mathrm{MJ}^{-1}$. Daily protein deposition also increased (from 98 up to $133 \mathrm{~g}$; $\mathrm{P}<0.05$ ). However, increasing the Lys:ME ratio from 0.59 to $0.71 \mathrm{~g} \mathrm{MJ}^{-1}$ did not increase daily gain or protein deposition.
\end{abstract}

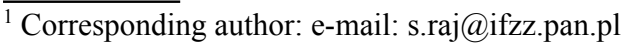


These results indicate that the optimal Lys:ME ratio in diets containing wheat and rapeseed meal and supplemented with crystalline lysine was $0.55 \mathrm{~g} \mathrm{MJ}^{-1}$ when referred to growth rate or $0.60 \mathrm{~g}$ $\mathrm{MJ}^{-1}$ if daily protein deposition in the body was considered.

KEY WORDS: pig, rapeseed meal, digestible lysine:energy ratio

\section{INTRODUCTION}

Modern, fast-growing pigs require a higher concentration of lysine and energy in diets as compared with slower growing animals. To achieve maximum growth, diet formulations should be based on the lysine:energy ratio. Numerous studies have explored the relationship between total amino acids (lysine) and dietary energy (Batterham et al., 1985; Chiba et al., 1991; Lawrence et al., 1994), however, there is less information on the optimal apparent ileal digestible lysine:metabolizable energy (Lys:ME) ratio for the first fattening period, and ratios ranging from 0.52 to $0.70 \mathrm{~g} \mathrm{MJ}^{-1}$ have been reported (Martinez and Knabe, 1990; Roth et. al., 2000). The optimal value of this index is usually determined based on growth rate (Roth et. al., 2000), nitrogen retention, and meatiness of the carcass (Lawrence et al., 1994) or protein deposition in the body (Bikker, 1994).

Until now the lysine:energy ratio for growing pigs was determined in cerealsoyabean diets supplemented with meat and bone meal. Recently for economical reasons and withdrawal of meat meals from pigs' diets in most European countries, increasingly more attention is being paid to plant-origin protein components. In Poland rapeseed meal, which has an important position on the Polish feed market, is being studied in this context. The nutritional value of rapeseed meal for pigs is, however, inferior to soyabean meal because of rapeseed meal's lower lysine content and availability, and its content of glucosinolates. However, lowglucosinolate (up to $5 \mathrm{mM} \mathrm{kg}^{-1}$ ) rapeseed meals can be a good source of protein in pig diets. The performance of pigs fed such diets is comparable to animals fed cereal-soyabean diets (Thomke et al., 1998).

The aim of the present study was to establish the optimal lysine:energy ratio in a diet for modern pigs during their intensive growth (from 25 to $70 \mathrm{~kg}$ ) based on growth rate and protein deposition when a low-glucosinolate $\left(4.4 \mathrm{mM} \mathrm{kg} \mathrm{kg}^{-1}\right)$ rapeseed meal was the only high protein component.

\section{MATERIAL AND METHODS}

The study was carried out on 20 gilts growing from 25 to $70 \mathrm{~kg}$ body weight (BW). The gilts with a high protein gain potential (about $145 \mathrm{~g} \mathrm{~d}^{-1}$; Raj et al., 2000) originated from Polish synthetic line 990. The pigs were allocated to 4 groups and 
were fed a basal diet (group 1) or the basal diet partially or adequately supplemented with crystalline amino acids (groups 2, 3 and 4). The composition of the basal diet $\left(\mathrm{g} \mathrm{kg}^{-1}\right)$ was as follows: wheat, 696; rapeseed meal, 220 (containing only $4.4 \mathrm{mM}$ $\mathrm{kg}^{-1}$ glucosinolates); maize starch, 60, and vitamin-mineral mixture, 24. In DM (g $\mathrm{kg}^{-1}$ ) the diet contained crude protein, 193; ether extract, 17; ash, 49 and gross energy, 18.8 MJ. The ileal apparent digestibility of AA in the wheat and rapeseed meal were determined in a separate experiment with surgically modified pigs (Buraczewska et al., 1999). Pigs of group 1 were fed the basal diet, which was not supplemented with any crystalline AA and was lysine-deficient. Group 2 was fed the basal diet supplemented with $0.21 \% \mathrm{~L}$-lysine $\cdot \mathrm{HCl}$, but was still deficient in comparison with the content of other essential amino acids (Table 1). Group 3 consumed a diet that was supplemented with $0.42 \% \mathrm{~L}$-lysine $\cdot \mathrm{HCl}, 0.018 \% \mathrm{~L}$-threonine and $0.015 \%$ L-tryptophan. Group 4 received a diet supplemented with $0.65 \%$ L-lysine $\cdot \mathrm{HCl}$ and $0.053 \%$ DL-methionine to maintain their mutual proportion of 100:32, however, the concentration of these AA was in excess of the requirement. Supplementation of crystalline AA to the basal diet was designed so that the diets contained a ratio of apparent ileal digestible lysine to metabolizable energy of $0.34(\operatorname{diet} 1), 0.47$ (diet 2), 0.59 (diet 3$)$ and $0.71\left(\mathrm{~g} \mathrm{MJ}^{-1}\right)$ (diet 4$)$, (Table 1). All mixtures were isoprotein (193 $\left.\mathrm{g} \mathrm{kg}^{-1} \mathrm{DM}\right)$ and isoenergetic (14.5 $\left.\mathrm{MJ} \mathrm{kg}^{-1} \mathrm{DM}\right)$. The methionine, threonine, and tryptophan contents in the diets were close to the recommendations of CVB (1995) and covered the pigs' requirements or were given in excess.

TABLE 1 Content of ileal digestible lysine (Lys), methionine (Met), treonine (The) and tryptophan (Trp) in the diets for growing pigs, $\%$

\begin{tabular}{lcccc}
\hline \multirow{2}{*}{ Amino acids } & \multicolumn{4}{c}{ Amino acids content in the diets, \% } \\
\cline { 2 - 5 } & 1 & 2 & 3 & 4 \\
\hline Lysine & 0.44 & $0.60(0.16)$ & $0.75(0.31)$ & $0.91(0.47)$ \\
Methionine & 0.24 & 0.24 & 0.24 & $0.29(0.05)$ \\
Threonine & 0.41 & 0.41 & $0.43(0.018)$ & 0.41 \\
Tryptophan & 0.12 & 0.12 & $0.14(0.015)$ & 0.12 \\
Lysine, $\mathrm{gMJ}^{-1}$ & 0.34 & 0.47 & 0.59 & 0.71 \\
Lys:Met:Thr:Try & $100: 55: 95: 28$ & $100: 40: 69: 20$ & $100: 32: 57: 18^{*}$ & $100: 32: 45: 13$ \\
\hline
\end{tabular}

in brackets is shown amount of crystalline amino acids; * standard (CVB,1995)

Pigs were kept individually in pens $\left(2.6 \mathrm{~m}^{2}\right)$, each equipped with a nipple drink and feeder, without bedding. Central heating and air conditioning systems in the piggery made it possible to keep the animals under thermo-neutral conditions (16$20^{\circ} \mathrm{C}$ ). Pigs were fed twice daily according to a scale adjusted to their metabolic BW $\left(120 \mathrm{~g} / \mathrm{kg}^{0.75}\right)$.

The gain of protein and fat in the body of pigs was measured by the comparative slaughter technique (Kotarbińska, 1971). After a $16 \mathrm{~h}$ period of starvation, the 
pigs were slaughtered at the beginning of the study at $25 \mathrm{~kg} \mathrm{BW}(\mathrm{n}=5)$ and at 70 $\mathrm{kg} \mathrm{BW}(\mathrm{n}=20$, five from each group). Total protein and fat accretion in the body was calculated from the difference between the final and initial BW. Chemical analyses were carried out according to the AOAC (1995) method. Gross energy in the feeds was determined by bomb calorimetry. Digestibility of energy was determined using an indicator method $\left(\mathrm{Cr}_{2} \mathrm{O}_{3}\right)$ during a three-day faeces collection in all pigs in the middle of the study, at approximately $45 \mathrm{~kg} \mathrm{BW}$. Metabolizable energy was estimated as digestive energy $\times 0.96$ (ARC, 1981). The glucosinolates of rapeseed meal were analysed by HPLC according to ISO-9167 (1991).

Data were subjected to statistical analysis using one-way ANOVA. A nonlinear regression analysis with means of treatments (groups) was conducted to determine the optimal Lys:ME ratio for daily gain and daily protein deposition in the body. In pigs, exponential response curves were fitted to the experimental data points using the following equation:

$$
\mathrm{Y}=\mathrm{a}+\mathrm{b}\left(1-\mathrm{e}^{-\mathrm{c}(\mathrm{x}-\mathrm{d})}\right)
$$

in which: $\mathrm{y}=$ response criteria (average daily gain or daily protein deposition, $\mathrm{g}$ ), $\mathrm{a}=$ intercept (average daily gain or daily protein deposition on the basal diet with a Lys:ME ratio of $0.34 \mathrm{~g} \mathrm{MJ}^{-1}$ ), $\mathrm{b}=$ maximal response (daily gain or protein deposition, $\mathrm{g}$ ) due to an increased Lys:ME ratio, $c=$ curvature slope, $x=$ Lys:ME ratio $\left(\mathrm{g} \mathrm{MJ}^{-1}\right)$ of the treatment groups, $\mathrm{d}=$ Lys:ME ratio $\left(\mathrm{g} \mathrm{MJ}^{-1}\right)$ of the basal diet. The tentative values for the optimal Lys:ME ratio were calculated at $90 \%$ of the asymptotic response.

\section{RESULTS}

The apparent ileal digestible lysine to metabolizable energy ratio in the diets had a marked effect on performance as well as on protein and fat deposition in the body of pigs (Table 2). The average daily weight gain of pigs increased $(\mathrm{P}<0.05)$ from 673 to $808 \mathrm{~g}$ and the feed conversion ratio decreased $(\mathrm{P}<0.05)$ from 3.14 to 2.58 as the Lys:ME ratio increased from 0.34 to $0.59 \mathrm{~g} \mathrm{MJ}^{-1}$.

Daily protein deposition also increased (from 98 up to $133 \mathrm{~g}, \mathrm{P}<0.05$ ), whereas a significant decrease of daily fat deposition (from 160 up to $142 \mathrm{~g} ; \mathrm{P}<0.05$ ) and the fat:protein ratio (from 1.63 up to $1.07 ; \mathrm{P}<0.05$ ) in daily gain of animals were noted. However, increasing the Lys:ME ratio from 0.59 to $0.71 \mathrm{~g} \mathrm{MJ}^{-1} \mathrm{did}$ not increase daily gain and daily protein deposition in the body (Table 2).

The optimal Lys:ME ratio differed depending on the animal response criteria applied (growth rate or protein deposition). Based on nonlinear regression analysis, carried out at $90 \%$ of the asymptotic response, it was recorded that the optimal Lys: ME ratio amounted to 0.55 if it was referred to growth rate criterion (Figure 1) or $0.60 \mathrm{~g} \mathrm{MJ}^{-1}$ if daily protein deposition in the body was considered (Figure 2). 
TABLE 2

Daily gain, feed conversion ratio, protein and fat deposition, and fat:protein ratio in daily gain of pigs fed diets with different apparent ileal digestible lysine to metabolizable energy ratio (Lys:ME, $g \cdot \mathrm{MJ}^{-1}$ )

\begin{tabular}{lccccc}
\hline & \multicolumn{4}{c}{ Diet/(Lys:ME, $\left.\mathrm{g} \mathrm{MJ}^{-1}\right)$} & \multirow{2}{*}{ SEM } \\
\cline { 2 - 5 } & $1 /(0.34)$ & $2 /(0.47)$ & $3 /(0.59)$ & $4 /(0.71)$ & \\
\hline Average daily gain, g & $673^{\mathrm{a}}$ & $778^{\mathrm{b}}$ & $808^{\mathrm{b}}$ & $808^{\mathrm{b}}$ & 7.07 \\
Feed conversion ratio, $\mathrm{kg} \mathrm{kg}^{-1}$ & $3.14^{\mathrm{b}}$ & $2.71^{\mathrm{a}}$ & $2.61^{\mathrm{a}}$ & $2.58^{\mathrm{a}}$ & 0.03 \\
Daily protein deposition, g & $98^{\mathrm{a}}$ & $122^{\mathrm{b}}$ & $133^{\mathrm{b}}$ & $132^{\mathrm{b}}$ & 1.98 \\
Daily fat deposition, g & $160^{\mathrm{b}}$ & $153^{\mathrm{ab}}$ & $142^{\mathrm{a}}$ & $141^{\mathrm{a}}$ & 4.09 \\
Fat:protein ratio & $1.63^{\mathrm{b}}$ & $1.25^{\mathrm{a}}$ & $1.07^{\mathrm{a}}$ & $1.07^{\mathrm{a}}$ & 0.15 \\
\hline
\end{tabular}

a, b $\mathrm{P}<0.05$

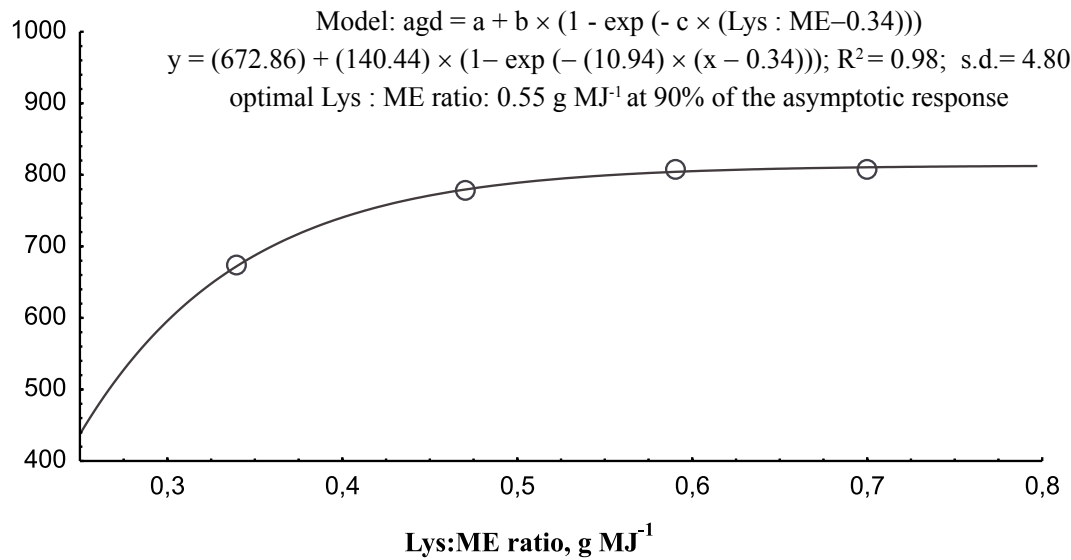

Figure 1. Exponential response curve of average daily gain to apparent ileal digestible lysine:metabolizable energy (Lys:ME) ratio in pigs growing from 25 to $70 \mathrm{~kg}$ BW. Each point represents mean from five pigs

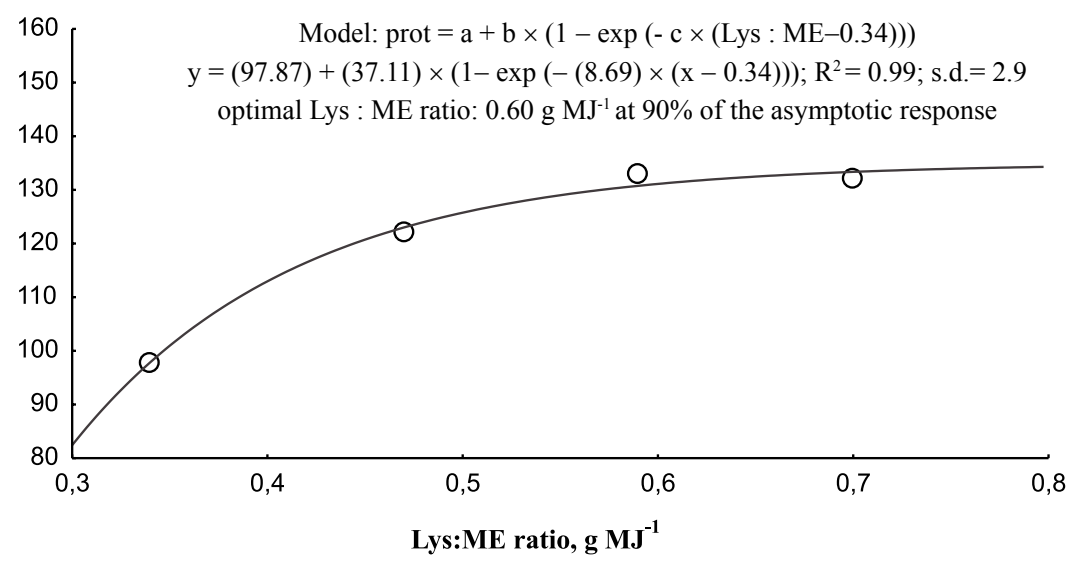

Figure 2. Exponential response curve of average daily protein deposition to apparent ileal digestible lysine: metabolizable energy (Lys:ME) ratio in pigs growing from 25 to $70 \mathrm{~kg}$ of BW. Each point represents mean from five pigs 


\section{DISCUSSION}

The basal diet (diet 1) as well as diet 2 were lysine-deficient, while diet 3 contained an adequate amount of AA and diet 4 had excess apparent ileal digestible lysine. Moreover, the dietary contents of methionine, threonine and tryptophan were close to the recommendations of CVB (1995) and covered the pigs' requirement or were given in excess. The lysine content in the diets was therefore the only factor influencing growth of the pigs and protein deposition in the body.

Two the most important criteria (average daily gain and daily protein deposition in the body) were taken into account in order to obtain the optimal ratio between Lys:ME in a wheat-rapeseed diet for fast-growing pigs; the diet had imbalanced ratios between essential AA (especially lysine to sulphur amino acids). Therefore supplementation of this diet with crystalline lysine resulted in increased average daily gain, protein deposition as well as decreased fat deposition in the body. On the other hand, excess lysine (diet 4) did not further increase growth or protein deposition rates, which emphasises the importance of the "ideal" protein in feeding of growing pigs. These results are consistent with the observation of Salter et al. (1990). These authors stated that the addition of sufficient lysine to meet the requirements of growing pigs fed a diet containing barley and soyabean meal resulted in a significant increase in $\mathrm{N}$ retention and protein accretion, however, excess lysine did not increase protein deposition.

Our results can also indicate that diet 3 had some nutrients (especially threonine) in excess. The pigs fed this diet grew only about $5 \%$ faster than pigs from group 2 (808 vs $\left.778 \mathrm{~g} \mathrm{~d}^{-1}\right)$ and their daily protein deposition in the body was about $9 \%$ higher, but this difference was not significant (133 vs $122 \mathrm{~g}$ ). This data suggests that a mixture containing wheat and rapeseed meal supplemented with only crystalline lysine $(0.42 \%)$ would have a threonine to lysine ratio equal to 0.55 , and consistent with the requirement of growing pigs. According to CVB (1995), this proportion should be at 0.57, though Saldana et al. (1994) determined much lower values: 0.44 and 0.42 for starter and finisher pigs, respectively, fed ad libitum. In another study on AA requirements of weaned pigs (Eggumm et al., 1990), daily gain and N-balance did not respond to an increased ratio of threonine to lysine ranging from 0.54 to 0.74 , when two levels of lysine in diets $(14.0$ or $16.6 \mathrm{~g} / \mathrm{kg} \mathrm{DM})$ were used.

The performance of animals fed a diet having adequate amounts and proportions of all essential AA confirms that wheat-rapeseed diets balanced according to ileal digestible AA can fully cover the protein requirements of fast-growing pigs, which is in agreement with previous works (e.g., Thomke et al., 1998).

Our data indicate that the ratio of Lys:ME had a significant influence on pig performance and protein deposition as well. As the Lys:ME ratio increased, protein deposition increased, but only up to the ratio of $0.59 \mathrm{~g} \mathrm{MJ}^{-1}$. At this ratio the pigs consumed an average of about $16.0 \mathrm{~g}$ of ileal digestible lysine daily, which 
was very close to the value recommended for growing pigs. As expected, ratios of 0.34 (diet 1) and $0.47 \mathrm{~g} \mathrm{MJ}^{-1}$ (diet 2) representing an absolute daily intake of 9.14 and $12.6 \mathrm{~g}$ of ileal digestible lysine, respectively, were insufficient and caused a sharp deterioration of animal performance and daily protein deposition. These findings are in a good agreement with previous studies by Bikker (1994) and Roth et al. (2000), who also found a similar response of animals. Several other studies also suggested the existence of a linear relationship between lysine requirement and energy intake in young pigs (e.g., Campbell and Dunkin, 1983).

The results of the present study indicate that the optimal Lys:ME ratio for pigs growing from 25 to $70 \mathrm{~kg}$ of $\mathrm{BW}$ and fed a wheat-rapeseed diet containing 12.8 MJ ME in DM should be higher if the response criterion is protein deposition in the body and lower if the response parameter is average daily gain. Similar results were reported by Batterham et al. (1990) and Bikker (1994) for pigs of similar body weight. The requirements in our experiment were $0.55 \mathrm{~g}$ apparent ileal digestible lysine per MJ of ME for average daily gain and 0.60 for protein deposition.

\section{CONCLUSIONS}

The results of our study indicate that wheat-rapeseed diets supplemented only with crystalline lysine can be successfully fed to fast-growing pigs to improve their performance as well as daily gain composition (protein and fat deposition). The lysine to metabolizable energy ratio estimated in our study proved that its optimal value depends on the animal response criterion used. If the response criterion is protein (nitrogen) deposition in the pig body, the ratio should be higher than for average daily gain. Our data indicate that pigs growing from 25 to $70 \mathrm{~kg} \mathrm{BW}$ and fed a wheat-rapeseed meal diet containing $12.8 \mathrm{MJ} \mathrm{ME} \mathrm{kg}^{-1}$ will be able fully maximise their growth rate or protein deposition at an apparent ileal digestible lysine to metabolizable energy ratio amounting to at least 0.55 and 0.60 , respectively.

\section{REFERENCES}

AOAC, 1995. Official Methods of Analysis, Association of Official Analytical Chemists. $16^{\text {th }}$ Edition. Arlington, VA

ARC, 1981. The Nutrient Requirements of Pigs. Commonwealth Agric. Bureaux, Slough (UK)

Batterham E.S., Andersen L.M., Baigent D.E., White E., 1990. Utilization of ileal digestible amino acids by growing pigs: effect of dietary lysine concentration on efficiency of lysine retention. Brit. J. Nutr. 64, 81-94

Batterham E.S., Giles LR., Dettmann E.B., 1985. Amino acid and energy interactions in growing pigs. 1. Effects of food intake, sex, and live weight on the responses of growing pigs to lysine concentration. Anim. Prod. 40, 331-343 
Bikker P., 1994. Protein and lipid accretion in body components of growing pigs: effects of body weight and nutrient intake. Ph.D. Thesis, Wageningen Agricultural University, Department of Animal Nutrition, Wageningen (The Netherlands), pp. 1-200

Buraczewska L., Wasilewko J., Fandrejewski H., Żebrowska T., Han K., 1999. Formulation of pig diets according to ileal digestible amino acid content. Livest. Prod. Sci. 52, 13-24

Campbell R.G., Dunkin A.C., 1983. The influence of dietary protein and energy intake on the performance, body composition and energy utilization of pigs growing from 7-19 kg. Anim. Prod. $36,185-192$

Chiba L.I., Lewis A.J., Peo E.R. Jr., 1991.Amino acid and energy interrelationship in pigs weighing 20 to 50 kilograms: 1. Rate and efficiency of weight gain. J. Anim. Sci. 69, 694-707

CVB, 1995. Table of Feedstuffs. Information about Composition, Digestibility and Feeding Value (in Dutch), No. 18, Central Veevoeder Bureau, Lelystad (The Netherlands)

Eggum B.O., Jørgensen H., Danilsen V., 1990. Lysine, methionine and threonine requirements for weaned pigs. Acta Agr. Scand. 40, 245-252

ISO-9167-1, Polish Standard, 1991. HPLC Method of Glucosinolates Determination (in Polish)

Kotarbińska M., 1971.The chemical composition of the body in growing pigs. Rocz. Nauk rol. B-93, 129-135

Lawrence B.V., Adeola O., Cline T.R., 1994. Nitrogen utilization and lean growth performance of 20 to 50 kilogram pigs fed diets balanced for lysine:energy ratio. J. Anim. Sci. 72, 2887-2895

Martinez G.M., Knabe D.A., 1990. Digestible lysine requirement of starter and grower pigs. J. Anim. Sci. $68,2748-2755$

Roth F.X., Eder K., Rademacher M., Kirchgessner M., 2000. Effect of apparent ileal digestible lysine to energy ratio on performance of growing pigs at different dietary metabolizable energy levels. J. Anim. Physiol. Anim. Nutr. 83, 181-192

Saldana C.J., Knabe D.A., Owen A.Q., Burgon K.G., Gregg E.J., 1994. Digestible threonine requirements of starter and finisher pigs. J. Anim. Sci. 72, 144-150

Salter D.N., Salter D.N., Montgomery A., Hudson A., Quelsch D.B., Elliott R.J., 1990. Lysine requirements and whole-body turnover in growing pigs. Brit. J. Nutr. 63, 530-513

Thomke S., Pettersson H., Neil M., Håkansson J., 1998. Skeletal muscle goitrin concentration and organ weights in growing pigs fed diets containing rapeseed meal. Anim. Feed Sci. Tech. 73, 207-215

\section{STRESZCZENIE}

\section{Wpływ proporcji pozornie strawnej lizyny (do końca jelita cienkiego) do energii metabolicznej w mieszance pszenno-rzepakowej na wzrost i odłożenie białka u rosnących świń}

Badania przeprowadzono na 20 loszkach (linii syntetycznej 990) o masie ciała od 25 do $70 \mathrm{~kg} \mathrm{w}$ celu określenia optymalnej proporcji pozornie strawnej lizyny do energii metabolicznej (Lys:ME) w mieszance pszenno-rzepakowej. Loszki podzielono na 4 grupy: świnie grupy pierwszej były żywione mieszanką podstawową, sporządzoną z pszenicy oraz ze śruty rzepakowej zawierającej glukozynolany w ilości $4,4 \mathrm{mM} \mathrm{kg}^{-1}$, bez uzupełnienia aminokwasami krystalicznymi. Pozostałe zwierzęta karmiono tą samą paszą, ale z różnym dodatkiem aminokwasów: świnie grupy 2 - z dodatkiem $0,21 \%$ L-lizyny $\cdot \mathrm{HCl}$ (niedoborowa pod względem lizyny); zwierzęta grupy 3 - z dodatkiem $0,42 \%$ L-lizyny $\cdot \mathrm{HCl}, 0,018 \%$ L-treoniny i 0,015\% L-tryptofanu; świnie grupy 4 ży- 
wiono paszą z dodatkiem $0,65 \%$ L-lizyny $\cdot \mathrm{HCl}$ i $0,053 \%$ DL-metioniny. Dieta ta miała właściwą proporcję lizyny do metioniny (100:32), jednak aminokwasy te występowały w nadmiarze w stosunku do zapotrzebowania rosnących świń. Wszystkie diety były izobiałkowe $\left(193 \mathrm{~g} \mathrm{~kg}^{-1} \mathrm{~s}\right.$.m. białka ogólnego) i izoenergetyczne (14,5 $\mathrm{MJ} \mathrm{kg}^{-1} \mathrm{~s} . \mathrm{m}$. EM). Zawartość metioniny, treoniny i tryptofanu była zbliżona do ilości zalecanych przez CVB (1995) lub w nadmiarze do zapotrzebowania tej kategorii świń. Zastosowane mieszanki różniły się proporcją Lys:ME, która wynosiła: $0,34 \mathrm{~g} \mathrm{w}$ grupie 1; $0,47 \mathrm{~g} \mathrm{w}$ grupie 2; 0,59 g w grupie 3 i 0,71 $\mathrm{g} \mathrm{w}$ grupie 4, w przeliczeniu na $1 \mathrm{MJ}$. Proporcję Lys:ME szacowano w odniesieniu do przyrostów lub dziennego odkładania białka w ciele, oznaczonego metodą ubojową. Dzienne przyrosty zwiększały się z 673 do $808 \mathrm{~g}$, a dzienne odkładanie białka z 98 do $133 \mathrm{~g}(\mathrm{P}<0,05)$ wraz ze zwiększaniem proporcji Lys:ME w paszy od 0,34 do 0,59 $\mathrm{g}$ $\mathrm{MJ}^{-1}$. Zwiększenie proporcji Lys:ME z 0,59 do 0,71 nie spowodowało zwiększenia badanych parametrów. Stwierdzono, że optymalna proporcja lizyny strawnej do energii metabolicznej w mieszance sporządzonej z pszenicy i niskoglukozynolanowej śruty rzepakowej, uzupełnionej lizyną krystaliczną zależała od zastosowanych kryteriów szacowania: dla osiągnięcia maksymalnych dziennych przyrostów wynosiła $0,55 \mathrm{~g} \mathrm{MJ}^{-1}$, dla uzyskania największego dziennego odkładania białka w ciele $0,60 \mathrm{~g} \mathrm{MJ}^{-1}$. Mieszanka ta nie wymaga uzupełnienia innymi aminokwasami. 